Pakistan Journal of Humanities and Social Sciences

April - June 2019, Volume 7, No. 2, Pages 245 - 256

\title{
High Performance Work System and Export Performance
}

\author{
Ramaisa Aqdas ${ }^{1}$, Nik Ab Halim Nik Abdullah ${ }^{2}$ \\ ${ }^{1} \mathrm{Ph} . \mathrm{D}$. Scholar, Department of International Business, School of International Studies, \\ Universiti Utara Malaysia \\ ${ }^{2}$ Associate Professor, Department of International Business, School of International Studies, \\ Universiti Utara Malaysia \\ Email: ramaisarana@gmail.com
}

\begin{abstract}
This paper aims to propose a conceptual framework about the relationship between high performance work system practices and export performance. HPWS is expected to play a crucial role in organizational success. Thus, this paper proposed a framework for studying the relationship among four dimensions of HPWS such as recruitment and selection, performance management, compensation and rewards and training and development and export performance in Pakistan's textile sector. Moreover, entrepreneurial orientation acts as the mediating factor among these variables. This framework is developed based on extensive literature and this study is expected to contribute towards knowledge by delivering insights and pointing out ways to increase country's export performance. Specifically, this research will benefit Pakistan's textile sector in formulating strategies to increase manufacturer's export performance.
\end{abstract}

Keywords: High performance work system, recruitment and selection, performance management, compensation and rewards, training and development, export performance, entrepreneurial orientation

\section{Introduction}

In today's competitive business environment, employees are the most crucial asset for organizations as they are unique and inimitable, while all other resources such as financial and technological resources are easily imitable. So it is the human resources (HR) factors which plays the important role for organizational competitiveness (Rahman, Ab Hamid, \& Mustaffa, 2018). In order to succeed, organizations need to attract those human resources who are skilled and talented. Nowadays due to globalization, diverse workforce and advance technology, firms that implement traditional HR practices are unable to perform well (Shazadi, Nadeem, Nisar, 
\& Azeem, 2017), so there is a drastic need to develop those HR in organizations who are more efficient, skilled and can cope up with severe competition. Clearly, there is a need to convince organization's employees to come up with new ways of organizing work and increasing their performance, efficiency and commitment which made possible through implementation of high performance work system (HPWS).

HPWS comprises of interrelated HR practices that focuses on effectiveness and productivity to attain sustainable competitive advantage (Pereira, Fontinha, Budhwar, \& Arora, 2018). Although association between HPWS and performance is widely elucidated but less attention is given among the association between HPWS and export performance especially in Pakistani textile sector. Pakistan's textile sector is contributing an important role in empowering country's economic growth. It contributes up to $25 \%$ in Pakistan's GDP and among the largest sector that provides employment opportunities for the people. But this sector is facing innumerable challenges both internally as well as externally which has minimized Pakistan's export performance by $4.5 \%$ in 2017 (Ikram \& Siddiqui, 2019). Since the last decade this sector has faced sluggish growth and country's export are continuously declining. Among the reasons identified in previous research are lack of skilled human resource, poor product innovation and lack of technological advancement (Rasheed et al., 2017).

This study purposes to investigates the importance of HPWS on textile manufacturers' export performance, and in what way country can improve its exports by implementing HPWS.

\section{Literature Review}

\section{A. Export Performance}

Exporting is a significant mean of entering foreign market that boosts country's sales (Chung, Ding, \& Ma, 2019) and it is considered as essential mechanism for internationalization (Ferreras-Méndez, Fernández-Mesa, \& Alegre, 2019). There is lack of agreement on export performance operationalization (Imran, Aziz, \& Hamid, 2016). Despite the fact that export performance is vastly studied concept, still it remains most contentious and one of the least understood area. Exporting in international market is more complex in contrast to domestic market selling as export managers need to strive best of their abilities. In fact, for organizational success and performance, recently the focus of studies have been shifted from tangible to intangible resources (Monteiro, Soares, \& Rua, 2017). In order to attain competitiveness, particularly in international markets it is necessary that organizations have heterogeneous and unique collection of intangible and tangible resources (Ribau, Moreira, \& Raposo, 2019).

\section{B. High Performance Work System}


Organization's HR plays as most valuable and important asset for their organizational success and they act as a backbone for their organization. No organization can grow and survive without implementing effective HR practices. Due to increased globalization, competition and technological advancement, dramatic changes have been resulted in organizations and that's why organizations are now forced to move towards adopting efficacious HR practices known as high performance work system (HPWS) to attain organizational objectives more quickly (Jyoti \& Rani, 2019). HPWS comprises of bundles of HR practices which focuses on effectiveness and productivity to attain sustainable competitive advantage (Pereira et al., 2018). HPWS successful implementation is vital for organizational performance. In other words, it is system of HR processes that are designed to enhance employee skills, productivity and commitment (Federici, Boon, \& Den Hartog, 2019). Fu, Bosak, Flood, and Ma (2018), explains that HPWS are designed to enhance knowledge, performance of employees, commitment and their abilities so that they become source of competitive advantage.

Past researchers have proved that HPWS leads towards better performance and contributes a vital role in organizational success (M. U. Hassan, Nawaz, Abbas, \& Sajid, 2013; Obeidat, Mitchell, \& Bray, 2016; Zhang \& Morris, 2014). However, there is no consensus over HPWS conceptualization (Obeidat et al., 2016; Punia \& Garg, 2012) and that's why different authors have adopted different sets of HPWS (Garg, 2019). According to Jyoti and Rani (2017), Kundu, Kundu, Gahlawat, and Gahlawat (2016), Mihail and Kloutsiniotis (2016) and Murali (2016) HPWS is also known as high commitment HR practices, high performance work practices and high involvement work practices. Among various HPWS practices, recruitment and selection, performance management, compensation and rewards and training and development are among most important dimensions that are expected to play an important role in firm's export activities and performance.

\section{Recruitment and Selection}

Recruitment is defined as the procedure of attracting employees having right profile in terms of skills, experience, qualifications and having interest to work for organization. While selection is choosing the best and turning down the rest (Sarah, Sang, \& Ngure, 2018). Selecting right individual for the right job is essential step for organizational success. Attracting high quality human resource is the key challenge for any organization (Renwick, Redman, \& Maguire, 2013).

Nowadays organizations are more concerned about acquiring appropriate employees because they are most precious and crucial asset for any organization. Moreover, employees 
plays an essential role in creating competitiveness for the organization (Oaya, Ogbu, \& Remilekun, 2017; Sangeetha, 2010). Decision regarding recruitment and selection procedure impacts organization's future. Clearly, good hire in organization continues to multiply while bad hire reduces value and adds serious costs. Recruitment and selection has a significant influence on organizational performance (Rahman et al., 2018; Sheikh, Hasnu, \& Khan, 2016) and it creates conflict among employees if duties are not properly performed.

The important reason behind recruitment process is generation of eligible candidate's pool for selecting best candidate while purpose of selection is picking up suitable candidate. Recruitment plays an essential role in any organizational success as it is the main constituent in strategizing organization's overall resourcing. Moreover, there is a positive association among recruitment and selection and performance (Murage Sarah, Sang, Ngure, \& Sciences, 2018; Saddam \& abu Mansor, 2015; Sang, 2005). Extensive selection and recruitment process has substantial influence on skill and quality of potential employees thus improving firm's ability to enhancing organizational performance output. As recruitment and selection has influential impact on performance so it will also play a significant role in enhancing export performance.

\section{Performance Management}

Performance management is defined as a procedure through which employees are encouraged to improve their professional skills so that they can achieve their organizational objectives and goals in a better way (Ahmad, 2015). Performance management system (PMS) plays a crucial role in attaining organization's goals and objectives. Good PMS has an effect on organizational performance (Nura \& Osman, 2013). Effective implementation of PMS ensures all organizational employees know all the relevant information at right time and outcomes are equitably and fairly distributed. It also allows employees in understanding their job responsibilities and furthermore achieving their individual growth more quickly. Ugheoke, Al-Rawas, Isa, and Noor (2015), suggested that doing this, helps bringing positive change in organizational culture by setting agreed upon goals, prioritizing resources and informing managers to change or confirm existing policies in order to meet set goals

PMS helps in evaluating employee's current efficiency, finding gaps, investigating improvisation measures and setting future goals (Mishra, 2017). PMS motivates employees by providing them feedback on their performance and issuing them performance standards so that they can perform better (Chin, Yean, \& Yahya, 2017). PM is comparing predetermined objectives and goals with employee outputs. It plays a crucial role in organization's success as 
when employees know their desired targets, objectives and goals they put more efforts to achieve them (Qureshi, Hassan, \& Sciences, 2013). Employee performance management practices helps in employee's skill development. Additionally, their willingness to stay in organization is also enhanced. Effective performance management system has influential effect on performance (Decramer, Smolders, \& Vanderstraeten, 2013). As performance management system has significant impact on performance so it will also play an important role in enhancing export performance.

\section{Compensation and Rewards}

Compensation and rewards are commonly assumed to be the most powerful tool for connecting employee's interest to organizational interest. Compensation consists of tangible benefits and financial returns that motivates employee to perform well (Mohamad, Yahya, Ishak, \& Nordin, 2016). While, Hameed, Ramzan, and Zubair (2014), defines that compensation is benefit and output that employee receive in terms of pay and wages. Moreover, they can motivate employees to exert their utmost efforts to achieve organizational goals (Ahmad, 2015; Jackson, Renwick, Jabbour, \& Muller-Camen, 2011). Particularly, every organization should pay special attention to compensation of their staff in order to motivate and retain current employees while attracting potential employees. Attractive compensation and rewards enhances employee productivity and loyalty (Rahman et al., 2018).

Compensation strategies plays a crucial role in skilled employee's recruitment and retention. S. Hassan (2016), suggests that mostly firm's use performance based compensation to reward their employees that positively effects their performance. Performance of employee is increased when they are rewarded with satisfied compensation (Mohamad et al., 2016). Compensation and rewards also plays a crucial role in skilled employee's recruitment and retention. As when employees are satisfied with their compensation they will not think of leaving their organization. Moreover, it increases employee's willingness to work efficiently and effectively (S. Hassan, 2016). Positive relationship exists among compensation and organizational performance (Katou \& Budhwar, 2010; Mohamad et al., 2016; Rahman et al., 2018). As compensation and rewards has significant impact on performance so it will also play an essential role in enhancing export performance.

\section{Training and Development}

Increased competition has pressurized organizations to train their staff with best knowledge, abilities and skills to perform competently. Researchers have given much attention to employees training and development (Aragón, Jiménez, \& Valle, 2014; Ugheoke et al., 
2015), because according to Ballesteros-Rodríguez, De Saá-Pérez, and Domínguez-Falcón (2012), it not only improves employee's performance but organizational performance as well. Training and development plays an important role in preparing qualified, well trained and flexible workforce. Moreover, it ensures that right individual with necessary knowledge and characteristics are properly trained so that they can perform their job tasks cautiously and fit in the working environment. Training has a positive influence on organizational employees and they become more competitive because they learn new skills and knowledge (Muduli, 2015; Rahman et al., 2018).

Indeed, training and development is a process that emphasis on development of employee's knowledge, attitude, abilities and skills (Ahmad, 2015). Training focuses on educating organizational employees about technical standards, regulatory requirements and development of new technical skills in complying with standards and meeting such requirements. It also develops awareness among employees about organizational business strategies and goals (Jackson et al., 2011). Effective training plays a crucial role in achieving competition. Organizations need to invest on their human sources to enhance performance of their employees. Effective training increases knowledge and skill of employees which in turn increases organizational productivity (S. Hassan, Mahmood, \& Sciences, 2016). Training and development increases employees as well as organizational performance that results in enhancing overall performance of organization. Positive relationship exists between training and development and performance (Al-Qudah, Osman, Ab Halim, Al-Shatanawi, \& Sciences, 2014; Tahir, Yousafzai, Jan, Hashim, \& Sciences, 2014; Weru, Iravo, Sakwa, \& Sciences, 2013). As training and development has significant impact on performance so it will also play an important role in enhancing export performance.

\section{Gaps in Literature}

Although, innumerable researches have been done on HPWS and performance (ÚbedaGarcía, Claver-Cortés, Marco-Lajara, Zaragoza-Sáez, \& García-Lillo, 2017; Zhu, Liu, \& Chen, 2018) but still there are very limited researches that have been conducted on HPWS and export performance, specifically focusing on dimensions of HPWS. At the same time, there is lack of studies that focused on developing countries, especially in Pakistan's textile sector. Therefore, future study may fills the gap by focusing on these dimensions of HPWS and export performance.

\section{Proposed Research Framework}


On the basis of reviewing extensive literature and theoretical gaps, following framework is proposed. This research framework has four dimensions of HPWS which serves as independent variables while export performance serves as dependent variable. The theoretical foundation is based on the Resource Based View theory which provides theoretical background to support and validate the proposed framework. According to this theory, HPWS and EO are valuable, rare, inimitable and non-substitutable resources that gives sustainable competitive advantage, leading towards higher export performance (Barney, 1991). This study proposed that HPWS may have significant influence on export performance.

\section{Figure 1: Research Framework}

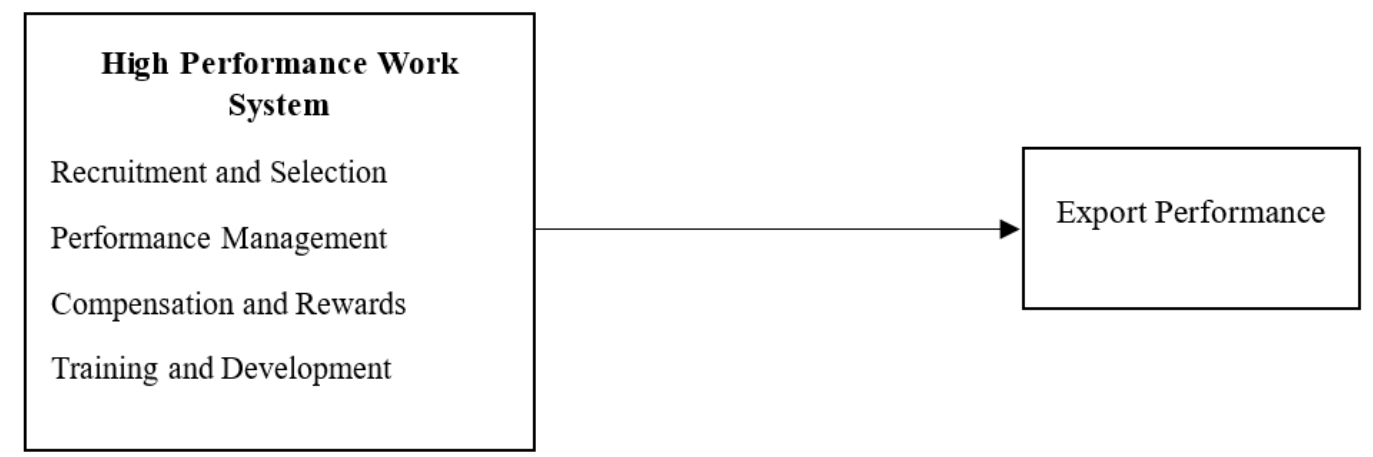

Source: The authors

\section{A. Propositions}

The following propositions are put forth, based on above reviewed literature:

Proposition 1: Recruitment and selection will have significant influence on export performance Proposition 2: Performance management will have significant influence on export performance Proposition 3: Compensation and rewards will have significant influence on export performance

Proposition 4: Training and development will have significant influence on export performance IV. Conclusion

HPWS is expected to play a significant role in improving export performance of an organization. Therefore, the purpose of this paper was to study previous research and identify the potential key role of HPWS dimensions on export performance. This proposed framework has several contributions regarding HPWS dimensions and export performance. If this proposed framework is validated, research findings will provide valuable information to managers that HPWS dimensions may provide significant contribution towards export performance. It is 
expected that HPWS implementation may leads towards positive increase in country's export performance. It also enhance labor productivity, customer satisfaction, product quality and organizational innovation.

This study highlights the importance of HPWS practices to sustain and achieve higher export performance and need for integrated approach for implementing and formulating of HPWS practices. Hopefully, managers can apply the findings of this proposed framework in order to boost export performance of their firms and at the same time will enhance country's exports activities and income. This study is also expected to be helpful for Pakistan's textile sector, especially in formulating strategies that could benefit this sector's export performance. Moreover it can increase employee performance as well because when HPWS practices are properly implemented, it ultimately enhances employee motivation and commitment.

\section{Directions for Future Research}

This paper presented the conceptual model that could be used in future studies to empirically test the constructs of this proposed framework, to practically examine role of HPWS on export performance. This paper suggested four dimensions of HPWS namely recruitment and selection, performance management, compensation and rewards, and training and development. Future studies may test these variables or may also include other dimensions of HPWS which are empowerment, participation, individual role and work life balance etc. This paper also focuses only on textile industry, and it is further recommended that in depth research is applied in multiple sectors of industry such as telecommunication, services, hotel and banking sector etc. Future researchers may conduct the in other countries or in multiple countries in order to have more evidence on the relationship among HPWS practices and export performance.

\section{References}

Ahmad, S. (2015). Green human resource management: Policies and practices. Cogent business \& management, 2(1), 1030817.

Al-Qudah, M. K. M., Osman, A., Ab Halim, M. S., Al-Shatanawi, H. A. J. I. J. o. A. R. i. B., $\&$ Sciences, S. (2014). The effect of human resources planning and training and development on organizational performance in the government sector in Jordan. 4(4), 79.

Aragón, M. I. B., Jiménez, D. J., \& Valle, R. S. (2014). Training and performance: The mediating role of organizational learning. BRQ Business Research Quarterly, 17(3), 161-173.

Ballesteros-Rodríguez, J. L., De Saá-Pérez, P., \& Domínguez-Falcón, C. (2012). The role of organizational culture and HRM on training success: evidence from the Canarian restaurant industry. The International Journal of Human Resource Management, 23(15), 3225-3242. 
Barney, J. (1991). Firm resources and sustained competitive advantage. Journal of management, 17(1), 99-120.

Chin, T. L., Yean, T. F., \& Yahya, K. K. (2017). Ability, Motivation, Opportunity Enhancing Human Resource Management and Corporate Environmental Citizenship: What's the Connection? Global Business \& Management Research, 9.

Chung, H. F., Ding, Z., \& Ma, X. (2019). Organisational learning and export performance of emerging market entrepreneurial firms: The roles of RBV mechanism and decisionmaking approach. European Journal of Marketing, 53(2), 257-278.

Decramer, A., Smolders, C., \& Vanderstraeten, A. J. T. I. J. o. H. R. M. (2013). Employee performance management culture and system features in higher education: relationship with employee performance management satisfaction. 24(2), 352-371.

Federici, E., Boon, C., \& Den Hartog, D. N. (2019). The moderating role of HR practices on the career adaptability-job crafting relationship: a study among employee-manager dyads. The International Journal of Human Resource Management, 1-29.

Ferreras-Méndez, J. L., Fernández-Mesa, A., \& Alegre, J. (2019). Export Performance in SMEs: The Importance of External Knowledge Search Strategies and Absorptive Capacity. Management International Review, 1-25.

Fu, N., Bosak, J., Flood, P. C., \& Ma, Q. (2018). Chinese and Irish professional service firms compared: Linking HPWS, organizational coordination, and firm performance. Journal of Business Research.

Garg, N. (2019). High performance work practices and organizational performance-mediation analysis of explanatory theories. International Journal of Productivity and Performance Management.

Hameed, A., Ramzan, M., \& Zubair, H. M. K. (2014). Impact of compensation on employee performance (empirical evidence from banking sector of Pakistan). International Journal of Business and Social Science, 5(2).

Hassan, M. U., Nawaz, M. S., Abbas, G., \& Sajid, M. I. (2013). Impact of high performance work practices on employee loyalty and financial performance through mediation of employee satisfaction: An empirical evidence from the financial sector of Pakistan. Middle-East Journal of Scientific Research, 16(8), 1037-1046.

Hassan, S. (2016). Impact of HRM practices on employee's performance. International Journal of Academic Research in Accounting, Finance and Management Sciences, 6(1), 15-22.

Hassan, S., Mahmood, B. J. I. J. o. A. R. i. A., Finance, \& Sciences, M. (2016). Relationship between HRM practices and organizational commitment of employees: An empirical study of textile sector in Pakistan. 6(1), 23-28.

Ikram, M. N., \& Siddiqui, D. A. (2019). Effect of Green supply chain management on environmental performance and export performance: A case study of Textile industries in Pakistan. Social Science and Humanities Journal, 1006-1019.

Imran, M., Aziz, A., \& Hamid, S. (2016). Moderating role of environmental turbulence on the relationship between entrepreneurial orientation, business networks orientation, export market orientation and SMEs export performance: a research framework. Journal of Business Management, Commerce \& Research, 4, 15.

Jackson, S. E., Renwick, D. W., Jabbour, C. J., \& Muller-Camen, M. (2011). State-of-the-art and future directions for green human resource management: Introduction to the special issue. German Journal of Human Resource Management, 25(2), 99-116.

Jyoti, J., \& Rani, A. (2017). High performance work system and organisational performance: role of knowledge management. Personnel Review, 46(8), 1770-1795. 
Jyoti, J., \& Rani, A. (2019). Role of burnout and mentoring between high performance work system and intention to leave: Moderated mediation model. Journal of Business Research, 98, 166-176.

Katou, A. A., \& Budhwar, P. S. (2010). Causal relationship between HRM policies and organisational performance: Evidence from the Greek manufacturing sector. European management journal, 28(1), 25-39.

Kundu, S. C., Kundu, S. C., Gahlawat, N., \& Gahlawat, N. (2016). High performance work systems and employees' intention to leave: Exploring the mediating role of employee outcomes. Management Research Review, 39(12), 1587-1615.

Mihail, D. M., \& Kloutsiniotis, P. V. (2016). The effects of high-performance work systems on hospital employees' work-related well-being: Evidence from Greece. European Management Journal, 34(4), 424-438.

Mishra, P. (2017). Green human resource management: A framework for sustainable organizational development in an emerging economy. International Journal of Organizational Analysis, 25(5), 762-788.

Mohamad, M. H., Yahya, K. K., Ishak, S., \& Nordin, R. (2016). The influence of compensation practice on performance of enforcement employees.

Monteiro, A. P., Soares, A. M., \& Rua, O. L. (2017). Linking intangible resources and export performance: the role of entrepreneurial orientation and dynamic capabilities. Baltic Journal of Management, 12(3).

Muduli, A. (2015). High performance work system, HRD climate and organisational performance: an empirical study. European journal of Training and development, 39(3), 239-257.

Murage Sarah, N., Sang, A., Ngure, S. J. I. J. o. A. R. i. B., \& Sciences, S. (2018). Ethical Issues in Recruitment, Selection and Employee Performance in Public Universities in Nyeri County, Kenya. 8(5).

Murali, V. (2016). Conceptualization of High Performance Work Practices-A Global Outlook.

Nura, A. A., \& Osman, N. H. (2013). Gauging the effect of performance management and technology based human resource management on employee retention: The perspective of academics in higher educational institutions in Sokoto State Nigeria. Asian Social Science, 9(15), 295.

Oaya, Z. C. T., Ogbu, J., \& Remilekun, G. (2017). Impact of Recruitment and Selection Strategy on Employees' Performance: A Study of Three Selected Manufacturing Companies in Nigeria. International Journal of Innovation and Economic Development, 3(3), 32-42.

Obeidat, S. M., Mitchell, R., \& Bray, M. (2016). The link between high performance work practices and organizational performance: Empirically validating the conceptualization of HPWP according to the AMO model. Employee Relations, 38(4), 578-595.

Pereira, V. E., Fontinha, R., Budhwar, P., \& Arora, B. (2018). Human resource management and performance at the Indian Railways. Journal of Organizational Change Management, 31(1), 47-61.

Punia, B., \& Garg, N. (2012). High performance work practices in Indian organisations: exploration and employees' awareness. Asia-Pacific Journal of Management Research and Innovation, 8(4), 509-516.

Qureshi, A., Hassan, M. J. I. J. o. A. R. i. E., \& Sciences, M. (2013). Impact of performance management on the organisational performance: An analytical investigation of the business model of McDonalds. 2(5), 54. 
Rahman, A. A., Ab Hamid, K., \& Mustaffa, J. (2018). Human Resource Management Practices and Performance in Malaysian SME: a proposed conceptual framework. Journal of Global Business and Social Entrepreneurship (GBSE), 4(10).

Rasheed, M. A., Rasheed, M. A., Shahzad, K., Shahzad, K., Conroy, C., Conroy, C., . . . Siddique, M. U. (2017). Exploring the role of employee voice between highperformance work system and organizational innovation in small and medium enterprises. Journal of Small Business and Enterprise Development, 24(4), 670-688.

Renwick, D. W., Redman, T., \& Maguire, S. (2013). Green human resource management: A review and research agenda. International Journal of Management Reviews, 15(1), 114.

Ribau, C. P., Moreira, A. C., \& Raposo, M. (2019). The role of exploitative and exploratory innovation in export performance: an analysis of plastics industry SMEs. European Journal of International Management, 13(2), 224-246.

Saddam, A. K., \& abu Mansor, N. N. J. R. o. E. S. (2015). The Role of Recruitment and Selection Practices in the Organizational Performance of Iraqi Oil and Gas Sector: A Brief Literature Review. 7(11), 348.

Sang, C. J. T. N. C. K. U. (2005). Relationship between human resource management practices and perception of organizational Taiwan performance, roles of management style, social capital, and culture: Comparison between manufacturing firms in Cambodia and Taiwan.

Sangeetha, K. (2010). Effective recruitment: A framework. IUP Journal of Business Strategy, 7(1/2), 93.

Sarah, M., Sang, A., \& Ngure, S. W. (2018). Ethical Issues in Recruitment, Selection and Employee Performance in Public Universities in Nyeri County, Kenya.

Shazadi, A., Nadeem, S., Nisar, Q. A., \& Azeem, M. (2017). Do High Performance Work Practices Influence The Job Outcomes? Mediating Role of Organizational Commitment \& Job Satisfaction: A Longitudinal Study. INTERNATIONAL JOURNAL OF ADVANCED BIOTECHNOLOGY AND RESEARCH, 8(4), 303-314.

Sheikh, M., Hasnu, S., \& Khan, I. (2016). Link between HR practices and organizational performance in small firms: A case for manufacturing sector of Pakistan. Management Science Letters, 6(1), 71-86.

Tahir, N., Yousafzai, I. K., Jan, S., Hashim, M. J. I. J. o. A. R. i. B., \& Sciences, S. (2014). The Impact of Training and Development on Employees Performance and Productivity A case study of United Bank Limited Peshawar City, KPK, Pakistan. 4(4), 86.

Úbeda-García, M., Claver-Cortés, E., Marco-Lajara, B., Zaragoza-Sáez, P., \& García-Lillo, F. (2017). High performance work system and performance: Opening the black box through the organizational ambidexterity and human resource flexibility. Journal of Business Research.

Ugheoke, S. O., Al-Rawas, N. M. A., Isa, M. F. M., \& Noor, W. S. W. M. (2015). Implementation of High Performance Work System in Public Organizations: Implication to Organizational Performance. Asian Social Science, 11(28), 139.

Weru, J. W., Iravo, M., Sakwa, M. J. I. J. o. A. R. i. B., \& Sciences, S. (2013). The relationship between training and development on performance of state owned corporations. 3(9), 57.

Zhang, B., \& Morris, J. L. (2014). High-performance work systems and organizational performance: testing the mediation role of employee outcomes using evidence from PR China. The International Journal of Human Resource Management, 25(1), 68-90. 
Zhu, C., Liu, A., \& Chen, G. (2018). High performance work systems and corporate performance: the influence of entrepreneurial orientation and organizational learning. Frontiers of Business Research in China, 12(1), 4. 